\title{
Development of a Chemically Defined Medium for Better Yield and Purification of Enterocin Y31 from Enterococcus faecium Y31
}

\author{
Wenli Liu, ${ }^{1,2}$ Lanwei Zhang, ${ }^{2,3}$ and Huaxi Yi $^{3}$ \\ ${ }^{1}$ College of Chemistry and Environmental Engineering, Shenzhen University, Shenzhen, Guangdong 518060, China \\ ${ }^{2}$ School of Food Science \& Technology, Harbin Institute of Technology, 73 HuangHe Avenue, Harbin, Heilongjiang 150090, China \\ ${ }^{3}$ College of Food Science and Engineering, Ocean University of China, Yushan Road 5, Qingdao, Shandong 266100, China \\ Correspondence should be addressed to Lanwei Zhang; zhanglw@hit.edu.cn and Huaxi Yi; yihx@ouc.edu.cn
}

Received 31 March 2017; Revised 17 July 2017; Accepted 2 August 2017; Published 6 September 2017

Academic Editor: Moreno Bondi

Copyright (C) 2017 Wenli Liu et al. This is an open access article distributed under the Creative Commons Attribution License, which permits unrestricted use, distribution, and reproduction in any medium, provided the original work is properly cited.

\begin{abstract}
The macro- and micronutrients in traditional medium, such as MRS, used for cultivating lactic acid bacteria, especially for bacteriocin production, have not been defined, preventing the quantitative monitoring of metabolic flux during bacteriocin biosynthesis. To enhance Enterocin Y31 production and simplify steps of separation and purification, we developed a simplified chemically defined medium (SDM) for the growth of Enterococcus faecium Y31 and production of its bacteriocin, Enterocin Y31. We found that the bacterial growth was unrelated to Enterocin Y31 production in MRS; therefore, both the growth rate and the Enterocin Y31 production were set as the index for investigation. Single omission experiments revealed that $5 \mathrm{~g} / \mathrm{L} \mathrm{NaCl}$, five vitamins, two nucleic acid bases, $\mathrm{MgSO}_{4} \cdot 7 \mathrm{H}_{2} \mathrm{O}, \mathrm{MnSO}_{4} \cdot 4 \mathrm{H}_{2} \mathrm{O}, \mathrm{KH}_{2} \mathrm{PO}_{4}, \mathrm{~K}_{2} \mathrm{HPO}_{4}, \mathrm{CH}_{3} \mathrm{COONa}$, fourteen amino acids, and glucose were essential for the strain's growth and Enterocin Y31 production. Thus, a novel simplified and defined medium (SDM) was formulated with 30 components in total. Consequently, Enterocin Y31 production yield was higher in SDM as compared to either MRS or CDM. SDM improved the Enterocin Y31 production and simplified the steps of purification (only two steps), which has broad potential applications.
\end{abstract}

\section{Introduction}

Bacteriocins are ribosomally synthesised antimicrobial proteins or protein complexes that inhibit other bacteria, and they either have a narrow antimicrobial spectrum (against the same species) or broad antimicrobial spectrum (against across genera) [1,2]. Bacteriocin produced by lactic acid bacteria (LAB) is generally regarded as safe (GRAS) and Qualified Presumption of Safety (QPS) status [3, 4], and it is a desirable trait as a food additive for extending the shelf-life of the fermented food and controlling the safety of foods $[5,6]$. Based on their molecular structure, bacteriocins can be divided into four groups: class I bacteriocins contain posttranslational modifications (lantibiotics and molecular weight $\leq 5 \mathrm{kDa}$ ); class II bacteriocins are unmodified and include small, heat-stable nonlanthioninecontaining peptides [7]. The third class includes large heat-labile bacteriocins. Finally, the fourth class comprises complex bacteriocins containing a protein moiety with one or more other lipids or carbohydrates [8]. Most bacteriocins produced by the Enterococcus faecium group of LAB are class II bacteriocins. One subgroup, class IIa, contains bacteriocins with certain sequence motifs in their $\mathrm{N}$-terminal halves and is active against the food pathogen, Listeria monocytogenes [9]. Class IIa bacteriocins have become a focus of research owing to their low molecular weight, good dispersity, and high thermostability. This is also a case of Enterocin Y31 produced by E. faecium Y31 in the current work [10].

Enterocin Y31 is a class IIa bacteriocin produced by E. faecium Y31 [11]. Previous research results showed that Enterocin Y31 had broad spectrum inhibition activity against Bacillus subtilis ATCC 6633, Escherichia coli ATCC 25922, Listeria monocytogenes ATCC 19111, Bacillus cereus CICC 20463, Staphylococcus aureus, and Salmonella enterica serovar 
Typhimurium ATCC 14028. The isoelectric point of Enterocin Y31 was 8.25; it was stable in both acidity and alkalescence conditions; hence, Enterocin Y31 has a broad application prospect (not published). However, two main drawbacks of Enterocin Y31 with regard to application in foods are as follows: (1) bacteriocins are secreted in very small quantities in the production media; and (2) the media used to grow the bacteriocin-producing strains are very complex [12], as the $\mathrm{LAB}$ are fastidious organisms requiring amino acids, B vitamins, and various minerals for their growth. These components are normally provided by sources such as soybean meal, yeast extract, and meat extract. All of these sources contain proteins and peptides as sources of amino acids, which are often very closely related to the bacteriocin produced. Therefore, purification of bacteriocin from such a complex medium requires a series of steps. At each step, there is some loss, and sometimes after the final purification, the antimicrobial activity may be completely lost. Complex media do not allow the examination of all individual medium factors $[13,14]$ affecting bacteriocin production.

Ricciardi reported a modified chemically defined medium to promote the growth of Lactobacillus casei and Lactobacillus plantarum groups [15]. In the present study, we improved the chemically defined medium to improve the yield of Enterocin Y31 produced by E. faecium Y31. There are four objectives of this study: (1) to develop a new and improved production method for Enterocin Y31 (produced by E. faecium Y31), (2) to determine the macro- and micronutrients necessary for cultivating E. faecium Y31 and improving Enterocin Y31 production, (3) to develop a novel and simple separation and purification method for Enterocin Y31 (avoiding a series of chromatography steps and the loss of Enterocin Y31 activity), and (4) to compare Enterocin Y31 production in a defined medium with that in a complex medium. This is feasible using a completely defined medium, and a minimal medium for bacteriocin production can thus be established.

\section{Materials and Methods}

2.1. Strains and Growth Conditions. The bacteriocin-producer strain E. faecium Y31 isolated from Chinese traditional fermented foods (fermented vegetable juice from Lanzhou) was previously found to produce class IIa bacteriocin [10], which was maintained as stock cultures in MRS medium with $18 \%$ glycerol at $-80^{\circ} \mathrm{C}$.

Escherichia coli ATCC 25922 was selected as a sensitive strain for antimicrobial activity assays, because the bacteriocin produced by $E$. faecium Y 31 has the highest activity against E. coli ATCC 25922 in gram-negative bacteria.

2.2. Medium. The growth of E. faecium $\mathrm{Y} 31$ and production of Enterocin Y31 in a defined medium in a fermenter were compared with those in MRS (reference medium) used for the optimisation of the growth of E. faecium Y31 and the production of Enterocin Y31. This medium CDM consisted of 44 components described by Khan et al. [12] (listed in Table 1). All chemicals used for the preparation of the defined medium were of analytical grade and obtained from either
Sigma-Aldrich (St. Louis, MO, USA) or BDH Chemicals Ltd. (Poole, UK). For all the experiments, aqueous stock solutions of the individual components were prepared in the appropriate concentrations and sterilized by autoclaving, with the exception of the heat-sensitive components. The heat-sensitive amino acids (asparagine, glutamine, and tryptophan), all of the $\mathrm{B}$ vitamins, and $\mathrm{FeSO}_{4}$ were filtersterilized (pore size $0.22 \mu \mathrm{m}$ membrane; Millipore Corp., Billerica, MA, USA). All the stock solutions were then stored at $4^{\circ} \mathrm{C}$ except $\mathrm{FeSO}_{4}$ which was freshly prepared before each experiment because it is prone to oxidation during storage. In addition to the defined medium, MRS medium was used as a reference for comparison with the defined medium before each experiment.

2.3. Determination of the Antimicrobial Activity of Enterocin Y31. The antimicrobial activity of bacteriocin was monitored using the agar well diffusion assay (AWDA) as described previously [16] with some modifications. E. faecium Y31 was cultured for two or three generations, and then the cellfree supernatants (CFSs) of E. faecium Y31 were prepared by centrifuging for $30 \mathrm{~min}$ at $10000 \times \mathrm{g}$. Aliquots $(80 \mu \mathrm{L})$ of the cell-free supernatants (CFSs) of E. faecium Y31 were added to the wells $(6 \mathrm{~mm}$ diameter $)$ on double-layer agar plates previously inoculated with $0.2 \mathrm{~mL}$ overnight culture of the indicator strain E. coli ATCC 25922. Plates were kept static at room temperature for $3 \mathrm{~h}$ to allow diffusion of the CFSs evenly in the agar, and then the plates were incubated for $24 \mathrm{~h}$ at $37^{\circ} \mathrm{C}$. The bacteriocin titre was determined by eliminating the effect of the organic acid, eliminating the effect of $\mathrm{H}_{2} \mathrm{O}_{2}$, and protease verification. The diameter of the zone of inhibition (not including the wells) was measured using a Vernier caliper. An arbitrary unit (AU/mL) was defined as the reciprocal of the highest dilution that produced an inhibition zone. Specific activity was expressed as that unit per milligram of protein.

2.4. Protein Concentration Determination. Protein concentration was determined by the BCA (bicinchoninic acid) microassay method (Pierce, Rockford, IL, USA) [17].

2.5. Monitoring of the Growth of E. faecium Y31. The OD value of the fermentation liquid of E. faecium Y31 was monitored with UV spectrophotometry at $600 \mathrm{~nm}$ each hour. Sterile culture medium was used as blanks to subtract the background value. Samples having an OD600 $\mathrm{nm}$ value of more than 0.7 were diluted with the sterile culture medium, and the corrected OD value was obtained by multiplying the dilution factor. ODmax $(600 \mathrm{~nm})$ represents the maximum OD value of the growth of E. faecium Y31. ODmax $(600 \mathrm{~nm})$ was calculated before any centrifugation.

2.6. Determination of the Relative Growth Rate. The relative growth rate was calculated according to Monod [18]. The following equation was used to calculate the growth rate:

$$
\mu=\left[\left(\ln \mathrm{OD}_{2}-\ln \mathrm{OD}_{1}\right) \div\left(t_{2}-t_{1}\right)\right] \div \mu_{\mathrm{CDM}},
$$

where $\mu$ is the relative growth rate $\left(\mathrm{h}^{-1}\right), \ln$ is the symbol for natural logarithm, and $\mathrm{OD}_{1}$ and $\mathrm{OD}_{2}$ are the corrected $\mathrm{OD}$. 
TABLE 1: Composition of CDM and SDM medium.

\begin{tabular}{|c|c|c|}
\hline \multirow{2}{*}{ Constituent } & \multicolumn{2}{|c|}{ Content } \\
\hline & $\mathrm{CDM}$ & SDM \\
\hline \multicolumn{3}{|l|}{ Amino acids $\left(\mathrm{g} \mathrm{L}^{-1}\right)$} \\
\hline L-Asparagine & 1.00 & 1.00 \\
\hline L-Aspartic acid & 1.00 & - \\
\hline L-Glutamic acid & 1.00 & 1.00 \\
\hline L -Glutamine & 1.00 & - \\
\hline L-Cys & 1.00 & 1.00 \\
\hline L-Alanine & 1.00 & - \\
\hline L-Arginine & 1.00 & 1.00 \\
\hline Glycine & 1.00 & 1.00 \\
\hline L-Histidine & 1.00 & 1.00 \\
\hline L-Isoleucine & 1.00 & 1.00 \\
\hline L-Leucine & 1.00 & 1.00 \\
\hline L-Lysine & 1.00 & 1.00 \\
\hline L-Methionine & 1.00 & 1.00 \\
\hline L-Phenylalanine & 1.00 & 1.00 \\
\hline L-Proline & 1.00 & - \\
\hline L-Serine & 1.00 & 1.00 \\
\hline L-Threonine & 1.00 & 1.00 \\
\hline L-Tryptophan & 1.00 & 1.00 \\
\hline L-Tyrosine & 1.00 & - \\
\hline L-Valine & 1.00 & - \\
\hline \multicolumn{3}{|l|}{ Nucleic acid bases $\left(\mathrm{g} \mathrm{L}^{-1}\right)$} \\
\hline Ademome. $\mathrm{SO}_{4}$ & 0.02 & 0.02 \\
\hline Guanine & 0.02 & - \\
\hline Inosine & 0.02 & - \\
\hline Xanthine & 0.02 & - \\
\hline Uracil & 0.02 & 0.02 \\
\hline Thymine & 0.02 & - \\
\hline Orotic acid & 0.02 & - \\
\hline \multicolumn{3}{|l|}{$\mathrm{B}$ vitamins $\left(\mathrm{mg} \cdot \mathrm{L}^{-1}\right)$} \\
\hline Biotin & 20.00 & 20.00 \\
\hline Para-aminobenzoic acid & 10.00 & - \\
\hline Nicotinic acid & 2.00 & 2.00 \\
\hline Ca-pantothenic acid & 20.00 & 20.00 \\
\hline Riboflavin & 2.00 & 2.00 \\
\hline Folic acid & 2.00 & 2.00 \\
\hline Cyanocobalamin & 2.00 & - \\
\hline Thiamine & 10.00 & - \\
\hline Pyridoxal & 20.00 & - \\
\hline \multicolumn{3}{|l|}{ Minerals $\left(\mathrm{g} \cdot \mathrm{L}^{-1}\right)$} \\
\hline Manganese sulfate & 0.05 & 0.05 \\
\hline Magnesium sulfate & 0.1 & 0.10 \\
\hline Ferrous sulfate. $7 \mathrm{H}_{2} \mathrm{O}$ & 0.02 & - \\
\hline $\mathrm{CaCl}_{2}$ & - & - \\
\hline Sodium citrate & 5.00 & 5.00 \\
\hline Potassium dihydrogen phosphate & 2.00 & 2.00 \\
\hline Dipotassium hydrogen phosphate & 7.00 & 7.00 \\
\hline
\end{tabular}

TABle 1: Continued.

\begin{tabular}{lcc}
\hline Constituent & \multicolumn{3}{c}{ Content } \\
\hline $\begin{array}{l}\text { Carbon source }\left(\mathrm{g} \cdot \mathrm{L}^{-1}\right) \\
\quad \text { Glucose }\end{array}$ & 15.00 & SDM \\
Others $\left(\mathrm{g} \cdot \mathrm{L}^{-1}\right)$ & & 15.00 \\
$\quad$ Tween 80 & 1.00 & \\
Glycerol & - & 1.00 \\
$\mathrm{NaCl}$ & - & - \\
\hline
\end{tabular}

2.7. Effects of $\mathrm{NaCl}, \mathrm{CaCl}_{2}$, and Glycerol on the Growth of E. faecium Y31 and Enterocin Y31 Production. To determine the effects of these components, $5 \mathrm{~g} / \mathrm{L}, 10 \mathrm{~g} / \mathrm{L}, 15 \mathrm{~g} / \mathrm{L}$, and $20 \mathrm{~g} / \mathrm{L}$ $\mathrm{NaCl}, 10 \mathrm{~g} / \mathrm{L} \mathrm{CaCl}$, and $50 \mathrm{~g} / \mathrm{L}$ glycerol were individually added to $1000 \mathrm{mLCDM}$, and CDM medium with no addtions was used as a control, wherein the inoculum size was $2 \%$, fermentation temperature was $37^{\circ} \mathrm{C}$, and inoculum time was $24 \mathrm{~h}$. The culturing liquid was then centrifuged for $20 \mathrm{~min}$ at $10000 \times \mathrm{g}$, and then the CFSs were used to determine Enterocin Y31 activity and ODmax (24 h).

2.8. Effects of Individually Omitting Each Amino Acid, B Vitamin, Mineral, and Nucleic Acid Base on the Growth of E. faecium Y31 and Enterocin Y31 Production. According to the Leave One Out (LOO) technique, each amino acid, B vitamin, mineral, and nucleic acid base was sequentially and individually omitted from $1000 \mathrm{~mL}$ CDM medium, and CDM without additions was used as a control. The inoculum size was $2 \%$, fermentation temperature was $37^{\circ} \mathrm{C}$, and inoculation time was $24 \mathrm{~h}$. The culture liquid was then centrifuged for $20 \mathrm{~min}$ at $10,000 \times \mathrm{g}$, and then the CFSs were used to determine Enterocin Y31 activity and ODmax (24 h).

The following terms were used to describe the relationship between each medium component and growth, as determined by the single omission technique. A constituent was considered essential if its omission resulted in less than half the maximum strain growth rate and production of bacteriocin of the positive control, stimulatory when its absence resulted in the fact that the growth rate and the bacteriocin production was between $50 \%$ and $80 \%$ of that observed in complete CDM, and nonessential if the growth rate and Enterocin Y31 production was $80 \%$ (or more) of that obtained in the complete CDM.

2.9. Purification of Enterocin $Y 31$. E. faecium $\mathrm{Y} 31$ was allowed to grow in the SDM (Table 1) for $24 \mathrm{~h}$. The cells were then removed by centrifugation $(11,800 \times \mathrm{g}, 25 \mathrm{~min})$. The CFSs were then filtered through a $022 \mu \mathrm{m}$ filter (low-proteinbinding HVLP filter; Millipore Corp.) to remove any remaining cells. These filtered CFSs were referred to as crude bacteriocin. The crude bacteriocin was subjected to ultrafiltration of $1 \mathrm{kDa}$ and $30 \mathrm{kDa}$. The retentate from the $1 \mathrm{kDa}$ step was then subjected to Tricine-SDS-PAGE.

2.10. Statistical Analyses. All experiments were preformed separately three times, and mean \pm standard deviation (SD) values were calculated from triplicate determinations. All 


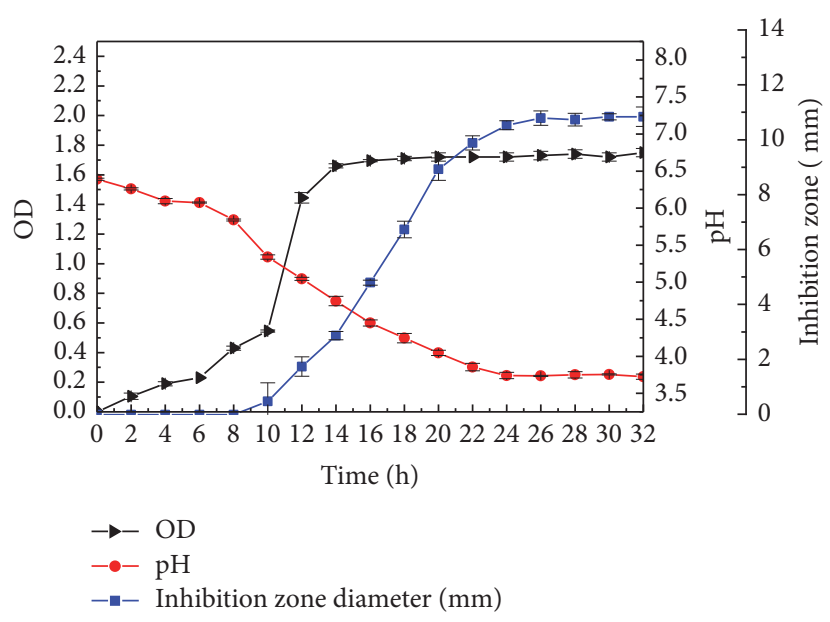

FIGURE 1: Relationship between the growth of the bacteriocinogenic strain and Enterocin Y31 production.

data were subjected to one-way analysis of variance (oneway ANOVA). Comparison of means was performed with Duncan's multiple range tests. Statistical significance was set at $P<0.05$.

\section{Results and Discussion}

3.1. Relationship between the Growth of the Strain and Enterocin Y31 Activity. The growth of E. faecium Y31 was unrelated to Enterocin Y31 activity in MRS medium, as shown in Figure 1. The result was consistent with the result of Bacterocin J23 produced by Lactobacillus paracasei J23 as described by Huaxi Yi in our research group (not published), which was inconsistent with the result of Salivaricin produced by $L$. salivarius CRL 1328 [19]; thus, the growth rate of $E$. faecium Y31 and Enterocin Y31 activity were used as detection indexes for developing a novel chemical defined medium. Enterocin Y31 activity could be detected at the exponential phase of the producing strain $(9 \mathrm{~h})$ and reached its highest value of $11.26 \pm 0.36 \mathrm{~mm}$ at stationary phase of producing strain $(24 \mathrm{~h})$. ODmax remained stable at $16 \mathrm{~h}$ of fermentation of strain Y31; thus, ODmax (16 h) was used as an index of the strain growth status.

3.2. Effect of $\mathrm{NaCl}$ Concentration on the Growth of E. faecium $\mathrm{Y} 31$ and Enterocin $\mathrm{Y} 31$ Production. The effect of $\mathrm{NaCl}$ at $5 \mathrm{~g} / \mathrm{L}$, $10 \mathrm{~g} / \mathrm{L}, 15 \mathrm{~g} / \mathrm{L}$, and $20 \mathrm{~g} / \mathrm{L}$ was determined in CDM with CDM with no additives as the control. The results indicated that the growth of E. faecium Y31 and production of Enterocin Y31 were not significant difference when adding $5 \mathrm{~g} / \mathrm{L}$ or $10 \mathrm{~g} / \mathrm{L} \mathrm{NaCl}$ and $0 \mathrm{~g} / \mathrm{L}$ and $15 \mathrm{~g} / \mathrm{L} \mathrm{NaCl}$ had no effect on the growth of strain Y31 and production of Enterocin Y31. When the concentration of $\mathrm{NaCl}$ was $20 \%$, the growth of $E$. faecium Y31 and production of Enterocin Y31 reduced, which showed the significant difference when compared to $0 \mathrm{~g} / \mathrm{L}$ and $15 \mathrm{~g} / \mathrm{L} \mathrm{NaCl}$. We can conclude that $20 \mathrm{~g} / \mathrm{L} \mathrm{NaCl}$ have a negative effect on the growth of strain $\mathrm{Y} 31$ and the production of Enterocin Y31. When the adding concentration of $\mathrm{NaCl}$ was $5 \mathrm{~g} / \mathrm{L}$, the ODmax $(16 \mathrm{~h})$ of E. faecium Y31 was highest

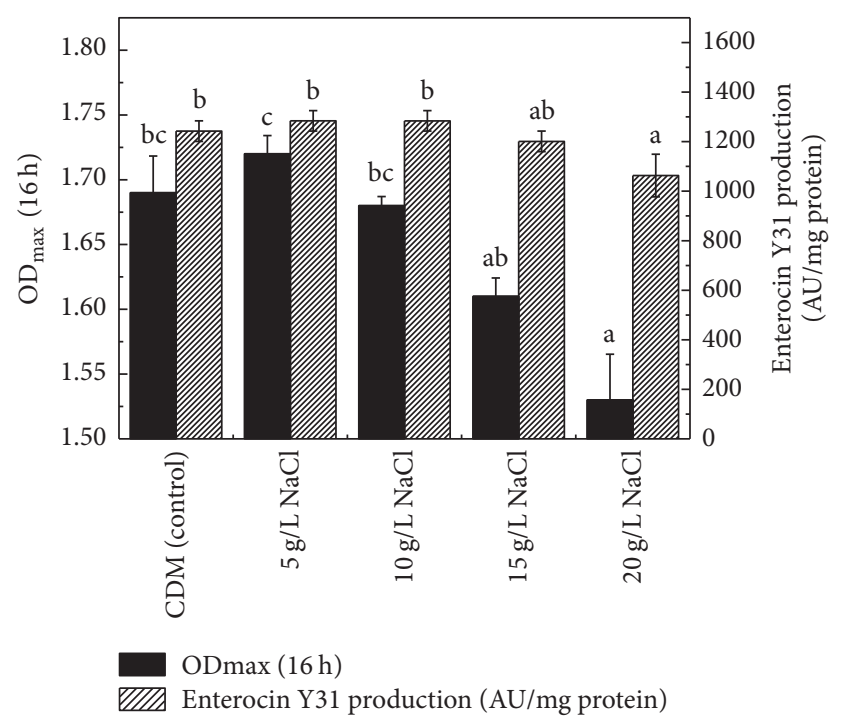

FIGURE 2: Effect of $\mathrm{NaCl}$ concentration on the growth of Enterococcus faecium Y31 and Enterocin Y31 production. Means not sharing a common superscript letter are significantly different from each other $(P<0.05)$.

$1.72 \pm 0.01$, and the antibacterial activity also reached the maximum value $1283.64 \pm 41.40 \mathrm{AU} / \mathrm{mg}$ protein. Based the significant difference analysis, we could conclude that $5 \mathrm{~g} / \mathrm{L}$ $\mathrm{NaCl}$ stimulated the growth of strain $\mathrm{Y} 31(P<0.05)$ and had no effect on the production of Enterocin Y31 (Figure 2). Similar results have been reported in a study of nutritional requirements of $L$. salivarius CRL 1328 producing Salivaricin [19]. Considering that the condition for the growth of $E$. faecium Y31 was crucial, $5 \mathrm{~g} / \mathrm{L} \mathrm{NaCl}$ was added to the novel chemically defined medium SDM (the medium ingredients of SDM were listed in Table 1).

3.3. Effect of $\mathrm{CaCl}_{2}$ and Glycerol on the Growth of E. faecium Y31 and Enterocin Y31 Production. The results shown in Table 2 indicated that adding $10 \mathrm{~g} / \mathrm{L} \mathrm{CaCl} 2$ to $\mathrm{CDM}$ had no effect on the growth of E. faecium Y31 but had a negative effect on the production of Enterocin Y31 $(P<0.05)$, whereas adding $50 \mathrm{~g} / \mathrm{L}$ glycerol had a slight negative effect on the growth of $E$. faecium $\mathrm{Y} 31(P<0.05)$ and a negative influence on Enterocin Y31 production $(P<0.05)$.

3.4. Effect of Individually Omitting Each Amino Acid, B Vitamin, Mineral, and Nucleic Acid Base on the Growth of E. faecium Y31 and Enterocin Y31 Production. According to the Leave One Out (LOO) technique, each amino acid, B vitamin, mineral, and nucleic acid base was sequentially omitted in a series of prepared formulations, along with $\mathrm{CDM}$ as a control. The results shown in Table 3 indicated that L-Arg, LGly, L-His, L-Leu, L-Met, L-Phe, L-Thr, L-Ser, and L-Cys are essential amino acids which had an effect on the growth of E. faecium Y31 and Enterocin Y31 production, and the stimulatory amino acids mainly included L-Asn, L-Glu, L-Iso, LLys, and L-Try. Omitting the stimulatory amino acids resulted in the slow growth of E. faecium Y31 and low production 
TABLE 2: Effects of $\mathrm{CaCl}_{2}$ and glycerol on the growth of Enterococcus faecium $\mathrm{Y} 31$ and Enterocin Y31 production.

\begin{tabular}{lcc}
\hline Added components & ODmax $(600 \mathrm{~nm})$ after $16 \mathrm{~h}$ & Enterocin Y31 production $($ AU/mg protein) \\
\hline None $(\mathrm{CDM})$ & $1.69 \pm 0.03^{\mathrm{b}}$ & $1242.24 \pm 41.41^{\mathrm{c}}$ \\
$10 \mathrm{~g} / \mathrm{L} \mathrm{CaCl}{ }_{2}$ & $1.70 \pm 0.02^{\mathrm{b}}$ & $289.86 \pm 41.41^{\mathrm{a}}$ \\
$50 \mathrm{~g} / \mathrm{L}$ glycerol & $1.53 \pm 0.03^{\mathrm{a}}$ & $565.91 \pm 41.81^{\mathrm{b}}$ \\
\hline
\end{tabular}

Note: CDM is explained in Table 1, and means in the same row not sharing a common superscript letter are significantly different from each other $(P<0.05)$.

TABle 3: Effect of omitting a single amino acid on the growth of Enterococcus faecium Y31 and Enterocin Y31 production.

\begin{tabular}{|c|c|c|c|}
\hline Omitted amino acid & ODmax $(16 h)$ & Relative growth rate & Enterocin $\mathrm{Y} 31$ production (AU/mg protein) \\
\hline None (CDM) & $1.69 \pm 0.03^{\mathrm{h}}$ & 100 & $1242.24 \pm 41.41^{\mathrm{cd}}$ \\
\hline L-Ala & $1.50 \pm 0.05^{\mathrm{g}}$ & 90 & $1228.43 \pm 63.25^{\mathrm{cd}}$ \\
\hline L-Arg & $0.76 \pm 0.02^{\mathrm{c}}$ & n.g. & $-^{\mathrm{a}}$ \\
\hline L-Asp & $1.43 \pm 0.04^{\mathrm{g}}$ & 93 & $1173.22 \pm 63.25^{\mathrm{cd}}$ \\
\hline L-Asn & $0.91 \pm 0.03^{\mathrm{d}}$ & 60 & $1228.43 \pm 82.25^{\mathrm{cd}}$ \\
\hline L-Cys & $1.00 \pm 0.04^{\mathrm{de}}$ & 44 & $-^{\mathrm{a}}$ \\
\hline L-Glu & $1.52 \pm 0.04^{\mathrm{g}}$ & 72 & $1104.20 \pm 23.91^{c}$ \\
\hline L-Gln & $1.71 \pm 0.04^{\mathrm{h}}$ & 84 & $1242.24 \pm 56.86^{\mathrm{d}}$ \\
\hline L-Gly & $0.61 \pm 0.03^{\mathrm{ab}}$ & n.g. & $-^{\mathrm{a}}$ \\
\hline L-His & $0.66 \pm 0.03^{b c}$ & n.g. & $-{ }^{\mathrm{a}}$ \\
\hline L-Iso & $1.06 \pm 0.04^{\mathrm{ef}}$ & 79 & $662.52 \pm 82.51^{\mathrm{b}}$ \\
\hline L-Leu & $0.71 \pm 0.03^{\mathrm{bc}}$ & n.g. & $-^{\mathrm{a}}$ \\
\hline L-Lys & $1.16 \pm 0.04^{\mathrm{f}}$ & 80 & $621.11 \pm 41.40^{\mathrm{b}}$ \\
\hline L-Met & $0.53 \pm 0.02^{\mathrm{a}}$ & n.g. & $-^{\mathrm{a}}$ \\
\hline L-Phe & $0.77 \pm 0.02^{c}$ & n.g. & $-^{\mathrm{a}}$ \\
\hline L-Pro & $1.81 \pm 0.03^{\mathrm{h}}$ & 71 & $1104.20 \pm 65.45^{\mathrm{cd}}$ \\
\hline L-Ser & $0.49 \pm 0.03^{\mathrm{a}}$ & n.g. & $-^{\mathrm{a}}$ \\
\hline L-Thr & $0.68 \pm 0.02^{\mathrm{bc}}$ & n.g. & $-^{\mathrm{a}}$ \\
\hline L-Try & $1.12 \pm 0.03^{\mathrm{ef}}$ & 80 & $573.22 \pm 23.91^{\mathrm{b}}$ \\
\hline L-Tyr & $1.70 \pm 0.07^{\mathrm{h}}$ & 100 & $1200.82 \pm 34.87^{\mathrm{cd}}$ \\
\hline L-Val & $1.96 \pm 0.08^{\mathrm{i}}$ & 98 & $1228.43 \pm 65.82^{\mathrm{cd}}$ \\
\hline
\end{tabular}

Note: "n.g." represents that the strain did not grow and "-_" represents that there was no inhibition activity. CDM is explained in Table 1 , and means in the same row not sharing a common superscript letter are significantly different from each other $(P<0.05)$.

of Enterocin Y31. Therefore, the essential amino acids and stimulatory amino acids were included in the SDM (listed in Table 1). A previous study reported the similar results, as Zhang et al. found that six amino acids (arginine, histidine, isoleucine, leucine, methionine, and valine) were necessary for the lactococci, enterococci, and streptococci [20].

Pyridoxal and pantothenic acid are essential $B$ vitamins which had an effect on the growth of E. faecium Y31 and Enterocin Y31 production, and the stimulatory B vitamins mainly included niacin and riboflavin. Wherein the stimulatory $\mathrm{B}$ vitamins could not result in the growth arrest of $E$. faecium Y31 and the biosynthesis arrest of Enterocin Y31, they could cause low growth rate and low biosynthesis volume. Therefore, the essential and stimulatory B vitamins were needed in the SDM. Omitting folic acid would cause a reduction of $80 \%$ in the ODmax (16 h) of E. faecium Y31; therefore folic acid is also needed for the growth of E. faecium Y31 and the production of Enterocin Y31 (Figure 3). It has been reported that nutritional requirements of $L$. delbrueckii ssp. lactis CRL 581 growth were nicotinic acid and pyridoxal and pantothenic acid, whereas the growth of $L$. delbrueckii ssp. lactis CRL 654 requires niacin and pantothenic acid, and riboflavin and cyanocobalamin were found to be stimulatory for both strains [21]. Research results about S. thermophilus strains (ST1, ST7, ST8, ST11, ST18, and ST21) indicated that riboflavin was essential for the growth of all strains, whereas Capantothenic acid and nicotinic acid were also required [22].

In the present study, $\mathrm{MgSO}_{4} \cdot 7 \mathrm{H}_{2} \mathrm{O}$ was an essential mineral and $\mathrm{MnSO}_{4} \cdot 4 \mathrm{H}_{2} \mathrm{O}, \mathrm{KH}_{2} \mathrm{PO} 4, \mathrm{~K}_{2} \mathrm{HPO}_{4}$, and $\mathrm{CH}_{3} \mathrm{COONa}$ were stimulatory minerals which had an effect on the growth of E. faecium Y31 and Enterocin Y31 production (Figure 4). The necessity of magnesium and phosphate has previously been reported by other researchers for various LAB species $[20,23,24]$.

Adenine and uracil are stimulatory nucleic acids which had an effect on the growth of E. faecium Y31 and Enterocin 


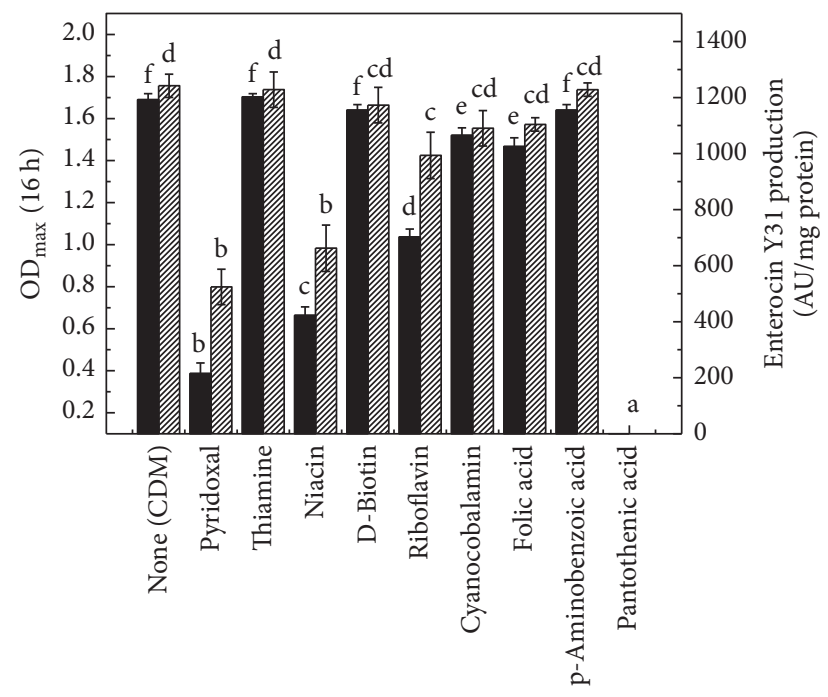

Omitted vitamins

$$
\begin{aligned}
& \mathrm{OD}_{\max }(16 \mathrm{~h}) \\
& \text { WIIt Enterocin } \mathrm{Y} 31 \text { production (AU/mg protein) }
\end{aligned}
$$

FIGURE 3: Effect of individually omitting each B vitamin on the growth of Enterococcus faecium Y31 and Enterocin Y31 production. Means not sharing a common superscript letter are significantly different from each other $(P<0.05)$.

Y31 production (Figure 5). No nucleic acid was essential for the growth of E. faecium Y31 and Enterocin Y31 production.

\subsection{Comparison of Enterocin Y31 Production on MRS Medium} and SDM. A novel chemical defined medium (SDM) was developed (Table 1 and Figures 3, 4, and 5), and SDM contained $\mathrm{NaCl}$, L-Arg, L-Gly, L-His, L-Leu, L-Met, L-Phe, LThr, L-Ser, L-Cys, L-Asn, L-Glu, L-Iso, L-Lys, L-Try, pyridoxal, pantothenic acid, niacin, riboflavin, folic acid, $\mathrm{MgSO}_{4} \cdot 7 \mathrm{H}_{2} \mathrm{O}$, $\mathrm{MnSO}_{4} \cdot 4 \mathrm{H}_{2} \mathrm{O}, \mathrm{KH}_{2} \mathrm{PO}_{4}, \mathrm{~K}_{2} \mathrm{HPO}_{4}, \mathrm{CH}_{3} \mathrm{COONa}$, adenine, and uracil. Strain Y31 grew better on SDM than on MRS medium (Figure 6). As shown in Figure 7, Enterocin Y31 production on SDM was 1.6 times than that on MRS.

3.6. Purification and Characterization of Enterocin Y31. After the removal of cells from the defined medium, the cellfree supernatant was subjected to ultrafiltration through a $30 \mathrm{kDa}$ ultrafiltration membrane. The active permeate liquor was then subjected to a second ultrafiltration step using a $1 \mathrm{kDa}$ NMWL. The antimicrobial activity was again found in the retentate (10240 AU/L). Enterocin Y31 was purified by Tricine-SDS-PAGE and its molecular weight was $6.74 \mathrm{kDa}$ (showed in Figure 8).

\section{Conclusion}

When culturing E. faecium Y31 using novel chemical defined medium (SDM) Enterocin Y31 production increased 1.6 times than that on MRS. The ingredients were composed of $\mathrm{NaCl}$, L-Arg, L-Gly, L-His, L-Leu, L-Met, L-Phe, L-Thr, L-Ser, L-Cys, L-Asn, L-Glu, L-Iso, L-Lys, L-Try, pyridoxal, pantothenic acid, niacin, riboflavin, folic acid, $\mathrm{MgSO}_{4} \cdot 7 \mathrm{H}_{2} \mathrm{O}$,

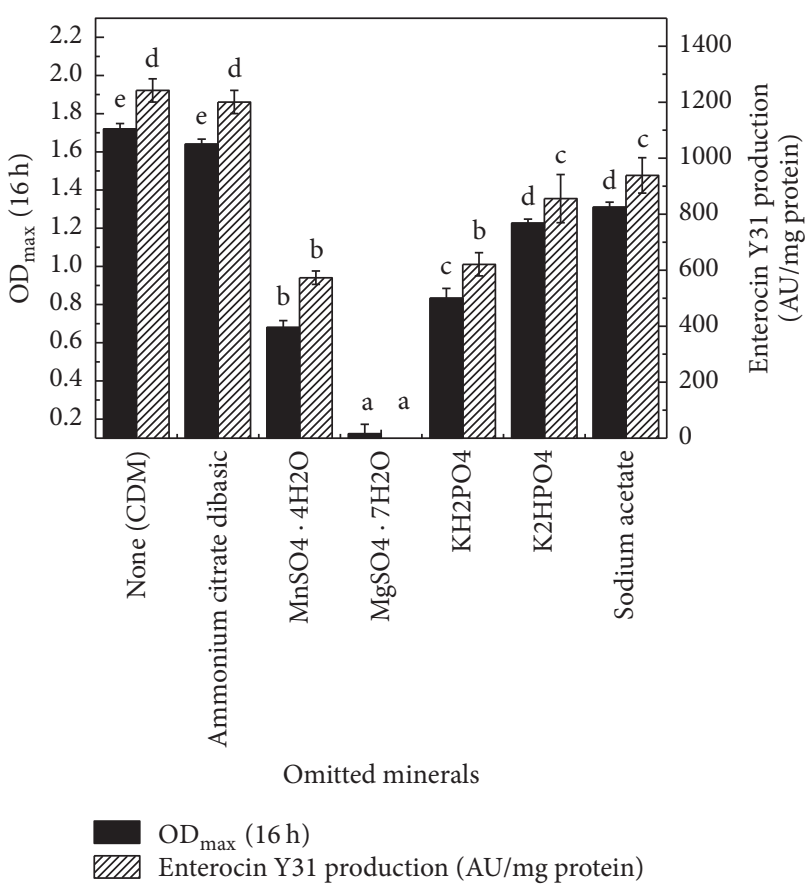

FIGURE 4: Effect of individually omitting each a mineral on the growth of Enterococcus faecium Y31 and Enterocin Y31 production. Means not sharing a common superscript letter are significantly different from each other $(P<0.05)$.

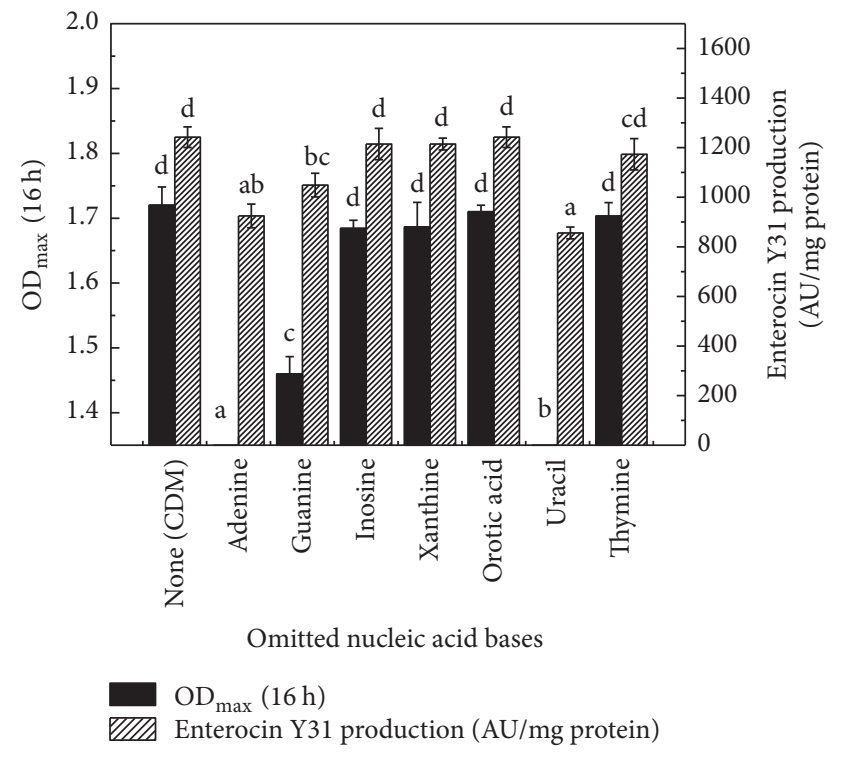

FIGURE 5: Effect of individually omitting each a nucleic acid base on the growth of Enterococcus faecium Y31 and Enterocin Y31 production. Means not sharing a common superscript letter are significantly different from each other $(P<0.05)$.

$\mathrm{MnSO}_{4} \cdot 4 \mathrm{H}_{2} \mathrm{O}, \mathrm{KH}_{2} \mathrm{PO}_{4}, \mathrm{~K}_{2} \mathrm{HPO}_{4}, \mathrm{CH}_{3} \mathrm{COONa}$, adenine, uracil, and glucose, which were the macro- and micronutrients needed by biosynthesis of Enterocin Y31. SDM was helpful to the growth of E. faecium Y31 and Enterocin Y31 production improvement. In addition, SDM avoided a series of chromatography steps and the loss of Enterocin Y31 


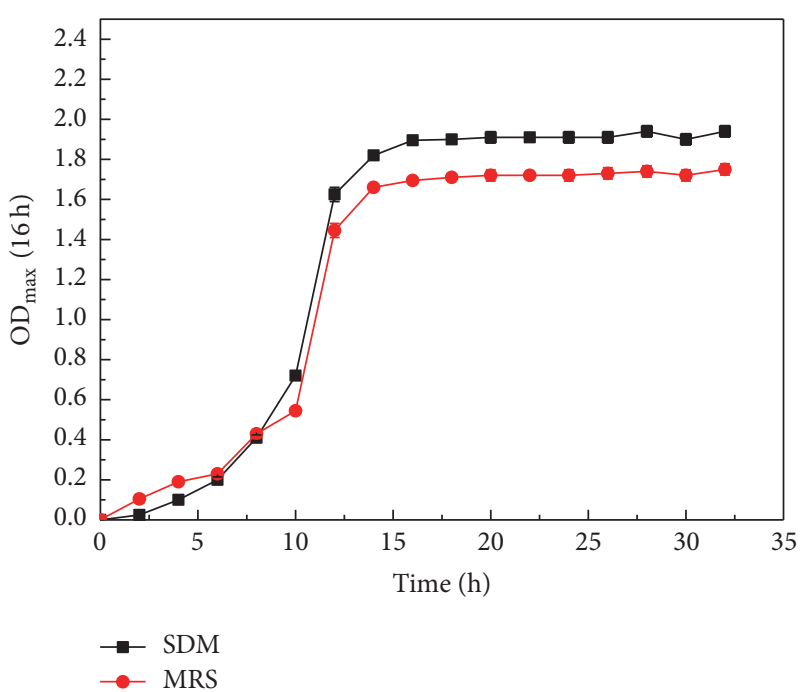

FIGURE 6: Growth of Enterococcus faecium Y31 on MRS and SDM.

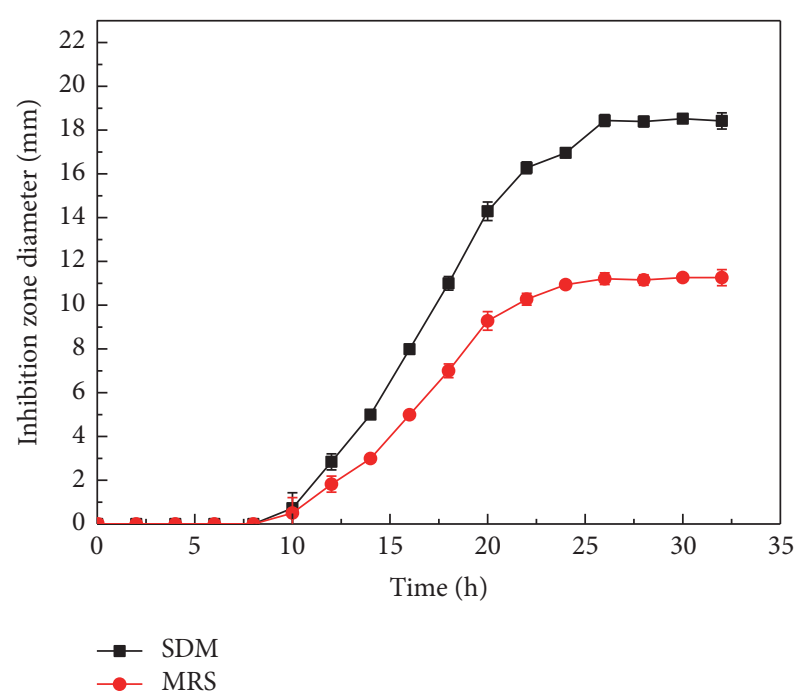

FIGURE 7: Enterocin Y31 productions on MRS and SDM.

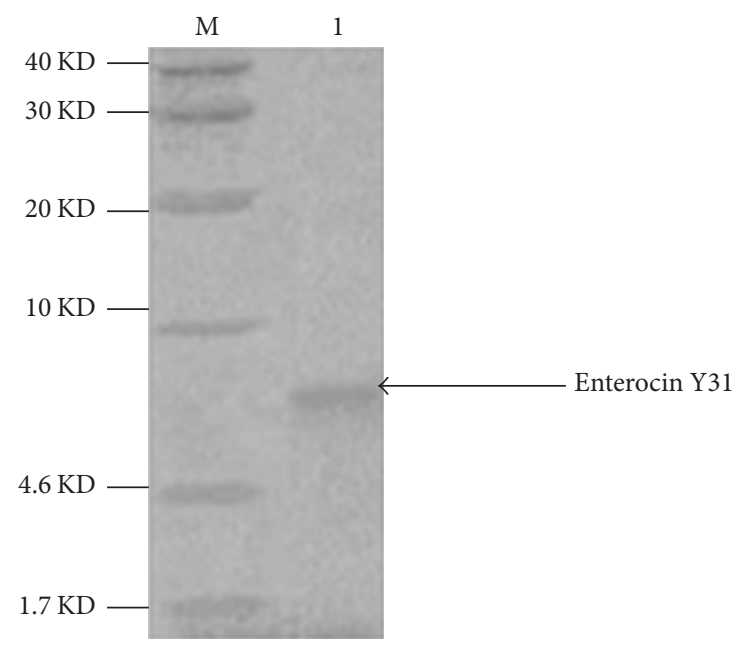

FIGURE 8: Tricine-SDS-PAGE of Enterocin Y31. M: protein marker; 1: Enterocin Y31. activity; only two steps of ultrafiltration and Tricine-SDSPAGE were needed to separate and purify Enterocin Y31. Therefore, chemically defined medium has better potential for improving the bacteriocin production and reducing the steps of separation and purification. Chemically defined media is useful for purification of not only large bacteriocins such as Enterocin Y31, but also small peptide bacteriocins. The alternative use of a chemically defined medium meets the nutritional requirements of strains producing bacteriocins and therefore is an excellent alternative to reduce the load of contaminating peptides from the medium, thereby decreasing the purification steps. To our knowledge, no such studies have been conducted to improve class IIa bacteriocin Enterocin Y31 production and purify Enterocin Y31.

\section{Ethical Approval}

This study complies with the research ethics guidelines and it does not contain any studies with human or animal subjects.

\section{Conflicts of Interest}

The authors declare that there are no conflicts of interest regarding the publication of this article.

\section{Acknowledgments}

This work was financially supported by the 60th Financial Grant from China Postdoctoral Science Foundation (Grant no. 2016M602534), the Youth Innovation Talents Project of General Higher School in Guangdong Province (2016KQNCX144), and the National Natural Science Foundation of China (Grants nos. 31571850, 31771988, and 31701621).

\section{References}

[1] R. C. R. Martinez, M. Wachsman, N. I. Torres, J. G. LeBlanc, S. D. Todorov, and B. D. G. D. M. Franco, "Biochemical, antimicrobial and molecular characterization of a noncytotoxic bacteriocin produced by Lactobacillus plantarum ST71KS," Food Microbiology, vol. 34, no. 2, pp. 376-381, 2013.

[2] I. M. Aasen, T. Møretrø, T. Katla, L. Axelsson, and I. Storrø, "Influence of complex nutrients, temperature and $\mathrm{pH}$ on bacteriocin production by Lactobacillus sakei CCUG 42687," Applied Microbiology and Biotechnology, vol. 53, no. 2, pp. 159-166, 2000.

[3] P. Alvarez-Sieiro, M. Montalbán-López, D. Mu, and O. P. Kuipers, "Bacteriocins of lactic acid bacteria: extending the family," Applied microbiology and biotechnology, vol. 100, no. 7, pp. 2939-2951, 2016.

[4] F. A. C. Martinez, E. M. Balciunas, A. Converti, P. D. Cotter, and R. P. De Souza Oliveira, "Bacteriocin production by Bifidobacterium spp. A review," Biotechnology Advances, vol. 31, no. 4, pp. 482-488, 2013.

[5] E. F. O'Shea, P. D. Cotter, R. P. Ross, and C. Hill, "Strategies to improve the bacteriocin protection provided by lactic acid bacteria," Current Opinion in Biotechnology, vol. 24, no. 2, pp. 130-134, 2013.

[6] A.-M. Zouhir, E. Kheadr, I. Tahiri, J. Ben Hamida, and I. Fliss, "Combination with plant extracts improves the inhibitory action of divergicin m35 against Listeria monocytogenes," Journal of Food Quality, vol. 31, no. 1, pp. 13-33, 2008. 
[7] J. Pei, Y. Yuan, and T. Yue, "Primary characterization of bacteriocin paracin C - A novel bacteriocin produced by Lactobacillus paracasei," Food Control, vol. 34, no. 1, pp. 168-176, 2013.

[8] D. Drider and S. Rebuffat, "Classification of Bacteriocins from Gram-Positive Bacteria," in Prokaryotic Antimicrobial Peptides, pp. 29-53, Springer New York, NY, USA, 2011.

[9] T. Aymerich, H. Holo, L. S. Håvarstein, M. Hugas, M. Garriga, and I. F. Nes, "Biochemical and genetic characterization of enterocin A from Enterococcus faecium, a new antilisterial bacteriocin in the pediocin family of bacteriocins," Applied and Environmental Microbiology, vol. 62, no. 5, pp. 1676-1682, 1996.

[10] W. Liu, L. Zhang, H. Yi et al., "Qualitative detection of class IIa bacteriocinogenic lactic acid bacteria from traditional Chinese fermented food using a YGNGV-motif-based assay," Journal of Microbiological Methods, vol. 100, no. 1, pp. 121-127, 2014.

[11] W. Liu, L. Zhang, J. Shi et al., "Assessment of the safety and applications of bacteriocinogenic Enterococcus faecium Y31 as an adjunct culture in North-eastern Chinese traditional fermentation paocai," Food Control, vol. 50, pp. 637-644, 2015.

[12] H. Khan, S. H. Flint, and P.-L. Yu, "Development of a chemically defined medium for the production of enterolysin A from Enterococcus faecalis B9510," Journal of Applied Microbiology, vol. 114, no. 4, pp. 1092-1102, 2013.

[13] M. Silva d, M. Andrade d S, A. Bauermeister et al., "A Simple Defined Medium for the Production of True Diketopiperazines in Xylella Fastidiosa and Their Identification by Ultra-Fast Liquid Chromatography-Electrospray Ionization Ion Trap Mass Spectrometry," Molecules, vol. 22, no. 6, p. 985, 2017.

[14] E. Texeira, J. Checa, A. Ríal et al., "A New Chemically Defined Medium for Cultivation of Streptococcus Pneumoniae Serotype," Journal of Biotech Research, vol. 6, p. 54, 2015.

[15] A. Ricciardi, R. G. Ianniello, E. Parente, and T. Zotta, "Modified chemically defined medium for enhanced respiratory growth of Lactobacillus casei and Lactobacillus plantarum groups," Journal of Applied Microbiology, vol. 119, no. 3, pp. 776-785, 2015.

[16] U. Schillinger and K. Lücke F, "Antibacterial activity of Lactobacillus sake isolated from meat," Applied and Environmental Microbiology, vol. 55, no. 8, pp. 1901-1906, 1989.

[17] P. K. Smith, R. I. Krohn, G. Hermanson et al., "Measurement of protein using bicinchoninic acid," Analytical biochemistry, vol. 150, no. 1, pp. 76-85, 1985.

[18] J. Monod, “The Growth of Bacterial Cultures," Annual Reviews in Microbiology, vol. 3, no. 1, pp. 371-394, 1949.

[19] E. V. Pingitore, E. M. Hebert, F. Sesma, and M. E. Nader-Macías, "Influence of vitamins and osmolites on growth and bacteriocin production by Lactobacillus salivarius CRL 1328 in a chemically defined medium," Canadian Journal of Microbiology, vol. 55, no. 3, pp. 304-310, 2009.

[20] G. Zhang, D. A. Mills, and D. E. Block, "Development of chemically defined media supporting high-cell-density growth of Lactococci, Enterococci, and Streptococci," Applied and Environmental Microbiology, vol. 75, no. 4, pp. 1080-1087, 2009.

[21] E. M. Hébert, R. R. Raya, and G. S. De Giori, "Nutritional requirements of Lactobacillus delbrueckii subsp. lactis in a chemically defined medium," Current Microbiology, vol. 49, no. 5, pp. 341-345, 2004.

[22] C. Letort and V. Juillard, "Development of a minimal chemically-defined medium for the exponential growth of Streptococcus thermophilus," Journal of Applied Microbiology, vol. 91, no. 6, pp. 1023-1029, 2001.
[23] N. Terrade and R. Mira de Orduña, "Determination of the essential nutrient requirements of wine-related bacteria from the genera Oenococcus and Lactobacillus," International Journal of Food Microbiology, vol. 133, no. 1-2, pp. 8-13, 2009.

[24] F. M. Saguir and M. C. M. De Nadra, "Improvement of a chemically defined medium for the sustained growth of Lactobacillus plantarum: nutritional requirements," Current Microbiology, vol. 54 , no. 6 , pp. $414-418,2007$. 

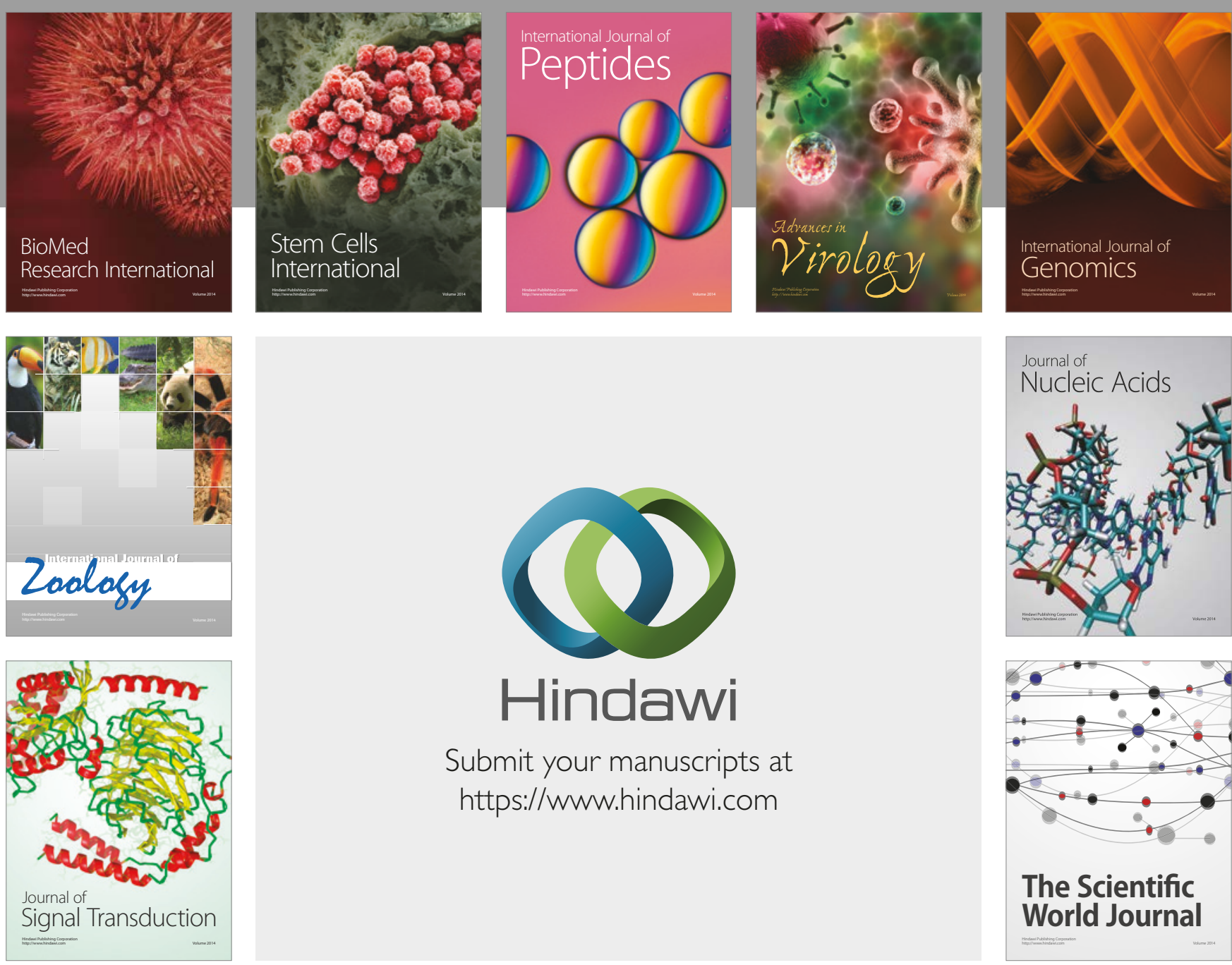

Submit your manuscripts at

https://www.hindawi.com
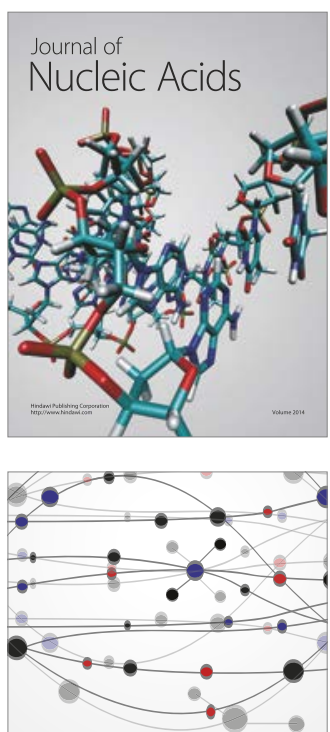

The Scientific World Journal

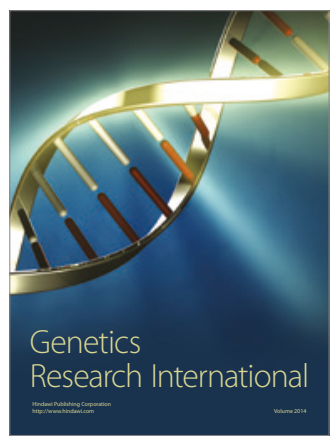

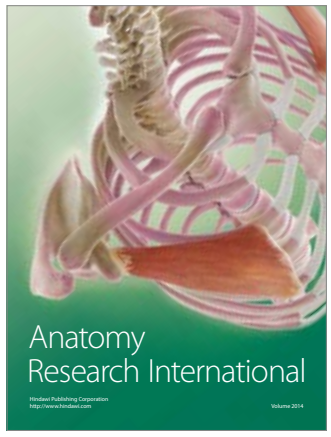

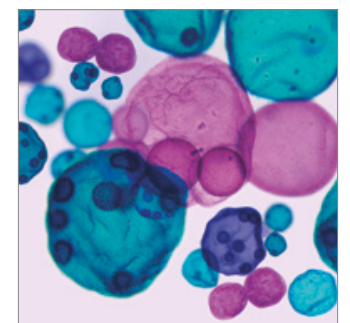

International Journal of Microbiology
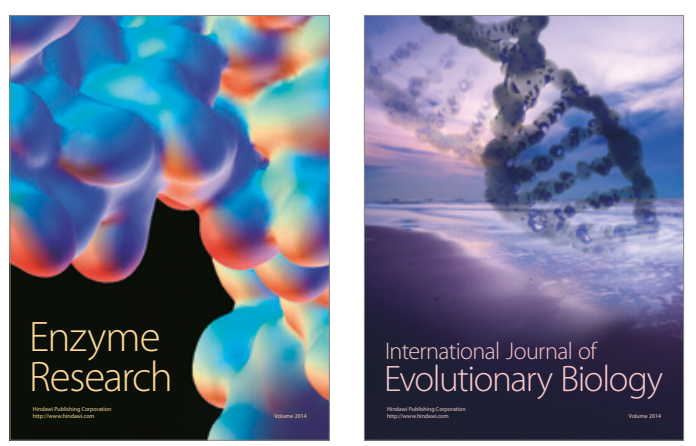
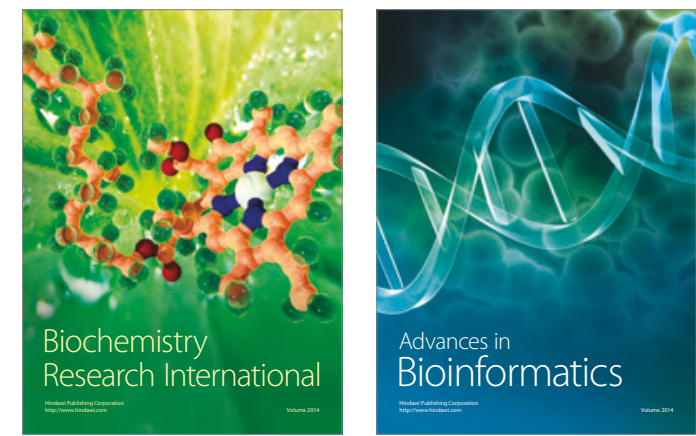

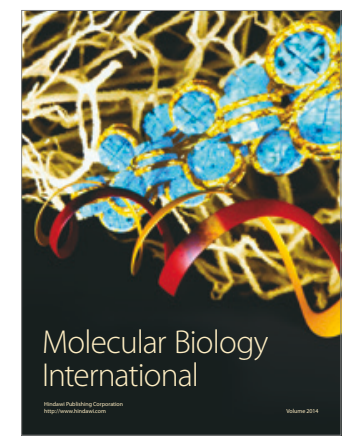

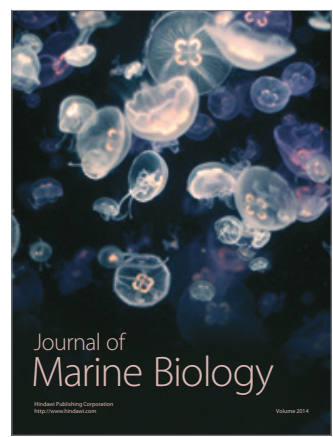

